Research article

\title{
EMERGING CHYTRID FUNGAL PATHOGEN, BATRACHOCHYTRIUM DENDROBATIDIS, IN ZOO AMPHIBIANS IN THAILAND
}

\author{
TECHANGAMSUWAN Somporn ${ }^{1,2, a}$, SOMMANUSTWEECHAI Angkana ${ }^{3, a}$, \\ KAMOLNORRANART Sumate ${ }^{3}$, SIRIAROONRAT Boripat ${ }^{3}$, KHONSUE \\ Wichase $^{4}$, PIRARAT Nopadon ${ }^{1 *}$
}

${ }^{1}$ STAR Wildlife, Exotic and Aquatic Pathology, Department of Pathology, Faculty of Veterinary Science, Chulalongkorn University, Bangkok 10330 Thailand; ${ }^{2}$ STAR Diagnosis and Monitoring of Animal Pathogen (DMAP), Faculty of Veterinary Science, Chulalongkorn University, Bangkok 10330 Thailand; ${ }^{3}$ Conservation Research and Education Division, Zoological Park Organization of Thailand, Dusit, Bangkok 10300 Thailand; ${ }^{2}$ Department of Biology, Faculty of Science, Chulalongkorn University,

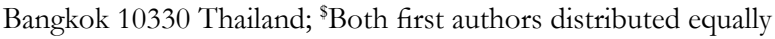

(Received 03 February, Accepted 28 June 2017)

Chytridiomycosis, a disease in amphibians caused by Batrachochytrium dendrobatidis (Bd), has led to a population decline and extinction of frog species since 1996. The objective of this study was to determine the prevalence of and the need for establishing a surveillance system for monitoring chytridiomycosis in five national zoos and five free ranging protected areas across Thailand. A total of 492 skin swab samples were collected from live and dead animals and tested by polymerase chain reaction (PCR) for the presence of $\mathrm{Bd}$. The positive specimens were confirmed by amplicon sequencing and examined by histopathology and immunohistochemistry. From July 2009 to August 2012, the prevalence of $\mathrm{Bd}$ from frog skin samples was low (4.27\%), monitored by PCR. All samples from live amphibians were negative. The positive cases were only from dead specimens $(21 / 168,12.5 \%$ dead samples) of two non-native captive species, poison dart frog (Dendrobates tinctorius) and tomato frog (Dyscophus antongilii) in one zoo. Immunohistochemistry and histopathology revealed the typical feature of flask-shaped zoosporangia and septate thalli, supporting the PCR-based evidence of chytridiomycosis in captive amphibians in Thailand, but detected Bd in only $7 / 21$ of the PCR-positive samples. Although the introduction of a pathogenic strain of $\mathrm{Bd}$ from imported carriers might have a serious impact on the native amphibian populations in Thailand, chytridiomycosis has not currently been detected in native Thai amphibians. An active surveillance system is needed for close monitoring of the fungus crossing into Thai amphibian populations.

Key words: Batrachochytrium dendrobatidis, chytridiomycosis, frog, Thailand

\footnotetext{
*Corresponding author: e-mail: nopadonpirarat@gmail.com

${ }^{\mathrm{a}}$ These authors contributed equally to the manuscript.
} 


\section{INTRODUCTION}

Chytridiomycosis is an emerging fungal disease in amphibians caused by the chytrid fungus, Batrachochytrium dendrobatidis (Bd) [1-3]. The disease markedly affected frog populations globally and resulted in the dramatic population decline and extinction of over 200 frog species since 1996 [4-5]. Chytridiomycosis has been increasingly reported in North, Central and South America, Australia, Europe, South Africa and Asia during the past decade [6-14]. Bd has been detected in almost 700 different amphibian species on every continent where amphibian exist [3,15-16]. Although discovered in 1998, retrospective studies revealed that Bd was detected in a native Japanese giant salamander (Andrias japonicus) preserved in the museum since 1902 [17] and in the skin of an African clawed frog (Xenopus laevis) collected in 1938 and kept in the museum [18]. The hypothesis that chytridiomycosis is spreading worldwide through the amphibian trade for scientific research has received a great deal of attention, and the widely distributed American bullfrog (Lithobates catesbeiana) has been proposed as a potential major reservoir of $\mathrm{Bd}[19-20]$.

Previous studies have indicated that, at least five evolutionarily divergent lineages of $\mathrm{Bd}$ exist with varying levels of virulence. The panzootic lineage (Bd-GPL) is globally distributed and appears to be the primary cause of the $\mathrm{Bd}$-driven declines of amphibian populations worldwide [3,15-16,21-23], while the other lineages are less virulent $[4,17,24-26]$. Several novel Bd genotypes that are deeply divergent from the potentially hypervirulent Bd-GPL are increasingly being described from geographic localities without any reported disease-associated amphibian declines [16,22-23]. This may suggest that the complex evolutionary history of $\mathrm{Bd}$ contains more novel branches that have yet to be discovered [27]. Understanding what lineage is infecting an individual would enable the refinement of quarantine and conservation measures [23].

Global climate change plays an important role in disease outbreaks and the extinction of amphibian populations [5]. Chytridiomycosis is now seen worldwide and has recently been reported in Asia. Indeed, parts of South East Asia have been predicted to be suitable for the establishment of $\mathrm{Bd}$, based upon the climate of the region [2829], while climate change and bioclimatic conditions in Asia are suitable for the further distribution of $\mathrm{Bd}$. Thailand, a seasonal evergreen rain and mixed moist deciduous country, harbors diverse amphibian species in the wild as well as native and introduced species in zoo captivity. Frog farming has also been widely invested in, and frogs are exported to Hong Kong, Singapore, Malaysia and Western Countries [30] as pets, food and bait, and as a source of traditional medicine. Chytridiomycosis was reported in the green puddle frog (Occidozyga lima) in Japan [14]. The green puddle frog is a commonly found species in Thailand and the occurrence of chytridiomycosis among Thai amphibian populations is highly possible. Indeed, Bd was also recently identified in imported poison dart frogs [31] in a captive zoo in Bangkok. To understand the status of chytridiomycosis in amphibian populations in Thailand, a survey and monitoring 
of the presence of $\mathrm{Bd}$, its strains and chytridiomycosis in captive and wild amphibians across the country was established and discussed in this study.

\section{MATERIALS AND METHODS}

\section{Study sites and amphibian species}

All procedures were conducted following the Chulalongkorn University guidelines for the care and use of animals (protocol No. 1631025). To determine the prevalence and disease status in captive and natural free-ranging amphibians in Thailand, the study areas were spread across five national zoos in the north, south, east, northeast and central area of the country and at the five natural free-ranging areas of HuawjarakaemakBuriram Reservoir, Jomthong-Chiang Mai, Chiang Dao-Chiang Mai, Nan-Inland Fisheries Station and Sai Yok, Kanchanaburi (Table 1 and Figure 1).

Table 1. Study sites and the number of live and dead samples examined

\begin{tabular}{lcccc}
\hline \multirow{2}{*}{ Study site and number1 } & \multicolumn{3}{c}{ Number of samples (cases) } \\
\cline { 2 - 4 } & National zoo & Natural free ranging areas & Total \\
\cline { 2 - 4 } & Live & Dead & Live & 8 \\
\hline 1. Zoo in Central Thailand (CZ) & 8 & 0 & 0 & 97 \\
2. Zoo in Eastern Thailand (EZ) & 33 & 16 & 48 & 62 \\
\hline 3. Zoo in Northern Thailand (NZ) & 13 & 0 & 49 & 214 \\
\hline 4. Zoo in Northeastern Thailand (NEZ) & 8 & 147 & 59 & 50 \\
\hline 5. Zoo in Southern Thailand (SZ) & 3 & 5 & 42 & 5 \\
\hline 6. Huawjarakaemak-Burirum Reservoir & 0 & 0 & 5 & 5 \\
\hline 7. Nan-Inland Fisheries Station & 0 & 0 & 5 & 31 \\
\hline 8. Jomthong-Chiang Mai & 0 & 0 & 31 & 10 \\
\hline 9. Chiang Dao-Chiang Mai & 0 & 0 & 10 & 10 \\
\hline 10. Sai Yok, Kanchanaburi & 0 & 0 & 10 & 492 \\
\hline Total & 65 & 168 & 259 & 59 \\
\hline
\end{tabular}

${ }^{1}$ The location of each study site is indicated by the above number (1-10) in Fig. 1.

Between July 2009 and August 2012 a total of 492 skin swabs were obtained from 168 dead and 65 live amphibians in captive zoos and from 259 live amphibians in natural free-ranging areas (198 samples from near the zoos and 61 from the other five protected areas). The number of each species of amphibians (68 species from 10 families) in these 492 samples is listed in Table 2. All new non-native amphibians 
that had been tested under the quarantine period in five zoos under the Zoological Park Organization, Thailand (No.1-5, Table 1 and Figure 1) and protected areas in the northeastern (No.6, Table 1 and Figure 1), northern (No.7-9, Table 1 and Figure 1) and western (No.10, Table 1 and Figure 1) part of Thailand were included.

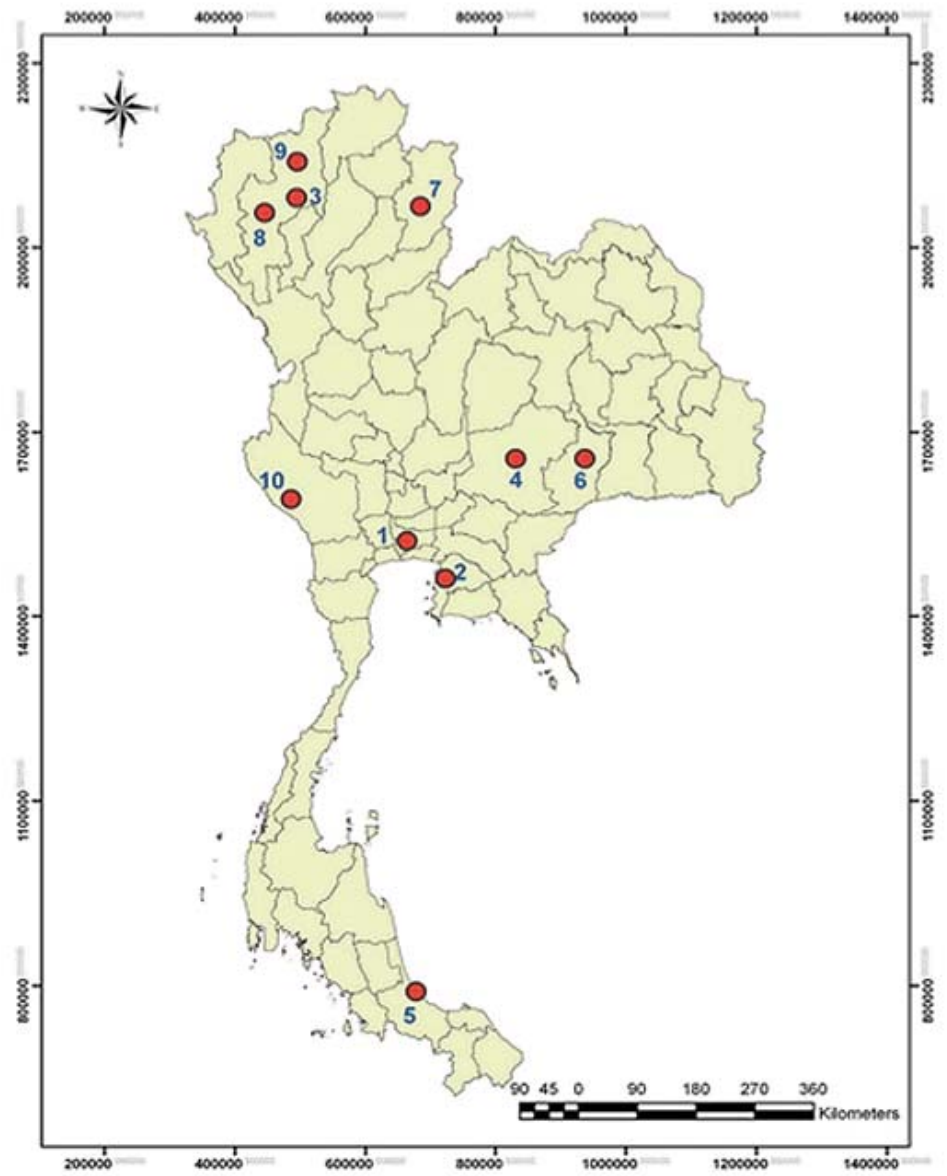

Figure 1. Map of the 10 sites sampled for detection of $\boldsymbol{B d}$. Numbers refer to the location given in Table 1. 
Table 2. Frogs sampled for Batrachochytrium dendrobatidis in Thailand

\begin{tabular}{|c|c|c|c|c|}
\hline Family & Species & $\begin{array}{l}\text { Number } \\
\text { of samples }\end{array}$ & $\begin{array}{c}\text { PCR } \\
\text { results }\end{array}$ & Location1 \\
\hline \multicolumn{5}{|c|}{ Ranidae (26) } \\
\hline & Amolops marmoratus & 19 & Negative & EZ (5), NEZ (1), Wild (13) \\
\hline & Eripaa fasciculispina & 4 & Negative & EZ (2), NEZ (2) \\
\hline & Ceratobatrachus guentheri & 1 & Negative & NEZ (1) \\
\hline & Fejervarya limnocharis & 12 & Negative & EZ (3), SZ (8), Wild (1) \\
\hline & Hoplobatrachus rugulosus & 12 & Negative & EZ (2), NZ (2),SZ (2), Wild (5), Private farm (1) \\
\hline & Hylarana erythraea & 6 & Negative & NEZ (5), SZ (1) \\
\hline & Ingerana tasanae & 1 & Negative & $\mathrm{NEZ}(1)$ \\
\hline & Limnonectes blythii & 24 & Negative & NZ (7), NEZ (2), SZ (13), Wild (2) \\
\hline & Limnonectes doriae & 1 & Negative & $\mathrm{NEZ}(1)$ \\
\hline & Limnonectes kublii & 17 & Negative & NZ (6), NEZ (1), Wild (9), Private farm (1) \\
\hline & Limnonectes macrognathus & 1 & Negative & NEZ (1) \\
\hline & Limnonectes pileatus & 6 & Negative & EZ (3), Wild (2), Private farm (1) \\
\hline & Occidozyga lima & 4 & Negative & NEZ (4) \\
\hline & Occidozyga martensii & 10 & Negative & EZ (3), NEZ (5), SZ (1), Private farm (1) \\
\hline & Odorana archotaphus & 2 & Negative & Wild (2) \\
\hline & Pulchrana glandulasa & 3 & Negative & $\mathrm{EZ}(1), \mathrm{NEZ}(1), \mathrm{SZ}(1)$ \\
\hline & Pyxicephalus adspersus & 3 & Negative & CZ (1), NZ (1), NEZ (1) \\
\hline & Rana catesbeiana & 9 & Negative & $\mathrm{CZ}(1), \mathrm{EZ}(4), \mathrm{NZ}$ (2), NEZ (2) \\
\hline & Rana cf. Livida & 1 & Negative & $\mathrm{EZ}(1)$ \\
\hline & Rana bosii & 3 & Negative & EZ (3) \\
\hline & Rana lateralis & 2 & Negative & NEZ (2) \\
\hline & Rana livida & 1 & Negative & $\mathrm{SZ}(1)$ \\
\hline & Rana mortenseni & 14 & Negative & $\mathrm{EZ}(14)$ \\
\hline & Rana nigrovittata & 21 & Negative & EZ (2), NZ (7),NEZ (3), Wild (9) \\
\hline & Rana raniceps & 1 & Negative & $\mathrm{SZ}(1)$ \\
\hline & Taylorana limborgi & 2 & Negative & NEZ (2) \\
\hline \multicolumn{5}{|c|}{ Megophryidae (7) } \\
\hline & Leptobrachiumbendricksoni & 3 & Negative & SZ (3) \\
\hline & Leptobrachium smithi & 5 & Negative & NEZ (1), SZ (3), Private (1) \\
\hline & Megophrys major & 1 & Negative & NEZ (1) \\
\hline & Megophrys nasuta & 4 & Negative & NEZ (4) \\
\hline & Megophrys parva & 1 & Negative & NEZ (1) \\
\hline & Xenophrys lekaguli & 4 & Negative & EZ (3), NEZ (1) \\
\hline \multicolumn{5}{|c|}{ Microbylidae (9) } \\
\hline & Calluella guttulata & 1 & Negative & NEZ (1) \\
\hline & Dyscophus antongilii & 8 & $\begin{array}{l}\text { Positive } \\
(1 / 8)\end{array}$ & EZ (1), NEZ (7) \\
\hline & Kalophrynus interlineatus & 7 & Negative & EZ (5), NEZ (2) \\
\hline
\end{tabular}




\begin{tabular}{|c|c|c|c|c|}
\hline & Kaloula pulchra & 13 & Negative & EZ (4), NZ (1), NEZ (4), SZ (4) \\
\hline & Micreletta inornata & 8 & Negative & EZ (2), NZ (3), NEZ (2), SZ (1) \\
\hline & Microbyla berdmorei & 2 & Negative & Wild (2) \\
\hline & Microbyla beymonsi & 11 & Negative & EZ (5), NZ (1), NEZ (4), Wild (1) \\
\hline & Microbyla ornata & 31 & Negative & EZ (3), NZ (16), NEZ (5), SZ (5), Wild (2) \\
\hline & Microbyla pulcbra & 2 & Negative & Wild (2) \\
\hline \multicolumn{5}{|c|}{ Bufonidae (7) } \\
\hline & Duttaphrynus melanostictus & 26 & Negative & EZ (3), NZ (2), NEZ (18), SZ (3) \\
\hline & Bombina orientalis & 1 & Negative & NEZ (1) \\
\hline & Bufo cristatus & 2 & Negative & NEZ (2) \\
\hline & Bufo divergens & 3 & Negative & NEZ (3) \\
\hline & Bufo macrotis & 4 & Negative & Wild (4) \\
\hline & Bufo marinus & 3 & Negative & EZ (2), NEZ (1) \\
\hline & Schismaderma carens & 1 & Negative & NEZ (1) \\
\hline \multicolumn{5}{|c|}{ Hylidae (4) } \\
\hline & Agalychnis callidryas & 11 & Negative & NZ (1), NEZ (10) \\
\hline & Litoria caerulea & 12 & Negative & CZ (2), NZ (2), NEZ (8) \\
\hline & Hyla gratiosa & 2 & Negative & NEZ (2) \\
\hline & Osteopilus septentrionalis & 3 & Negative & NEZ (3) \\
\hline \multicolumn{5}{|c|}{ Leptodactylidae (1) } \\
\hline & Ceratophrys ornate & 8 & Negative & CZ (4), NZ (2), NEZ (2) \\
\hline \multicolumn{5}{|c|}{ Rachophoridae (9) } \\
\hline & Chirixalus nongkhorensis & 15 & Negative & EZ (12), NEZ (2), Wild(1) \\
\hline & Nyctixalus pictus & 2 & Negative & NEZ $(2)$ \\
\hline & Polypedates leucomystax & 30 & Negative & EZ (12), NZ (1), NEZ (13), SZ (3), Wild (1) \\
\hline & Polypedates mutus & 4 & Negative & NZ (1), Wild (3) \\
\hline & Rhachophorus bipunctatus & 10 & Negative & NEZ (10) \\
\hline & Rhachophorus feae & 1 & Negative & NEZ (1) \\
\hline & Rhachophorus maximus & 2 & Negative & NEZ (2) \\
\hline & Rhacophorus nigropalmatus & 3 & Negative & NEZ (3) \\
\hline & Rhacophorus bisacculus & 5 & Negative & EZ (2), NEZ (3) \\
\hline \multicolumn{5}{|c|}{ Dendrobatidae (3) } \\
\hline & Dendrobates tinctorius auratus & 54 & $\begin{array}{l}\text { Positive } \\
(20 / 54)\end{array}$ & NZ (1), NEZ (53) \\
\hline & Dendrobates tinctorius azureus & 1 & Negative & NEZ (1) \\
\hline & Dendrobates tinctorius leucomelas & 1 & Negative & NEZ (1) \\
\hline \multicolumn{5}{|c|}{ Arthroleptidae (1) } \\
\hline & Leptopelis vermiculatus & 4 & Negative & NEZ (4) \\
\hline \multicolumn{5}{|c|}{ Pipadae (1) } \\
\hline & Pipa pipa & 4 & Negative & NEZ (4) \\
\hline Total & & 492 & $21 / 492(4$ & $.27 \%)$ \\
\hline
\end{tabular}




\section{Sampling technique}

The skin was sampled at three sites (gular, abdomen and pelvic patch) [32] by swabbing (Figure 2). Samples were kept in 95\% (v/v) ethanol under room temperature for 1-3 days before freezing at $-80{ }^{\circ} \mathrm{C}$ for storage until used for genomic DNA extraction and polymerase chain reaction (PCR) analysis.
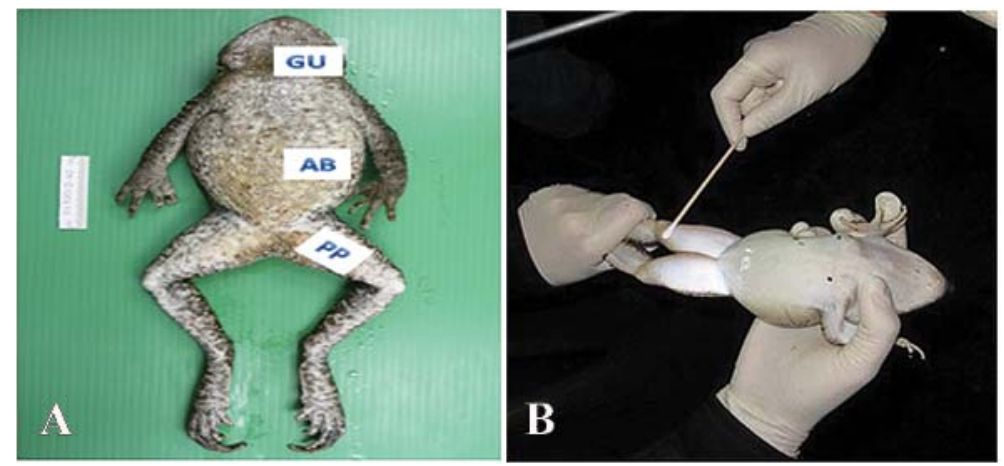

Figure 2. (A) Sampling areas of the body, which are common sites for Bd detection, were the gular $(\mathrm{GU})$, abdomen $(\mathrm{AB})$ and pelvic patch (PP). (B) All areas were swabbed using sterile cotton swabs.

\section{Molecular detection of Bd by PCR}

Genomic DNA was extracted from the swab samples using an ArchivePure DNA Purification kit (5 PRIME, Gaithersburg, MD, USA). The species-specific primers (Bd1a and $\mathrm{Bd} 2 \mathrm{a}$ ) for amplification of the internal transcribed spacer (ITS) regions (ITS1 and ITS2) of Bd and PCR reaction composition were used as previously reported [33]. Thermal cycling was performed as 45 cycles at $95^{\circ} \mathrm{C}$ for $40 \mathrm{sec}, 60^{\circ} \mathrm{C}$ for $1 \mathrm{~min}$ and $72{ }^{\circ} \mathrm{C}$ for $1 \mathrm{~min}$, followed by a final $72{ }^{\circ} \mathrm{C}$ for $5 \mathrm{~min}$ and held at $4{ }^{\circ} \mathrm{C}$. The PCR products were resolved on $2 \%(\mathrm{w} / \mathrm{v})$ agarose gel by electrophoresis and visualized by an ultraviolet transilluminator. For sensitivity testing, 10-fold DNA template dilutions were examined. For specificity testing, the selected positive band was purified using the GeneJET PCR Purification Kit (Fermentas, Thermo fisher scientific Waltham, MA, USA) and submitted for commercial direct sequencing (Solgent ${ }^{\mathrm{TM}}$, Daejeon, Korea) for both strands. The obtained sequences were compared with those deposited in the GenBank database (NCBI) using the BLASTn algorithm. The consensus ITS1ITS2 sequence of Bd (342 bp) was deposited in GenBank with accession number KU669287 (strain ZFT-CU1). Phylogenetic tree construction using the neighbor joining (NJ) distance based method was performed using the Mega 6 software [34].

\section{Histopathology}

To confirm the presence of chytrid fungus (assumed Bd) in the affected frog skin, the 21 PCR-positive skin samples (abdomen area) were collected and fixed in 10\% neutral 
buffered formalin and further processed for routine histopathology. The tissues were sectioned (5- $\mu \mathrm{m}$ thickness) and then stained with Hematoxylin and Eosin (H\&E) and Grocott's methenamine silver (GMS) prior to examination under light microscopy.

\section{Immunohistochemistry}

Skin samples were further processed for immunohistochemical analysis. After rehydration in a serial dilutions of ethanol with water, they were treated with $3 \%(\mathrm{v} / \mathrm{v})$ hydrogen peroxide in methanol for 20 min to block non-specific endogenous peroxidase activity, washed in phosphate buffer solution (PBS) and then blocked by incubation in $1 \%(\mathrm{w} / \mathrm{v})$ bovine serum albumin for $30 \mathrm{~min}$ prior to the addition of rabbit polyclonal anti-Bd antibody (1:200 dilution; courtesy by Dr. Yumi Une, Azabu University) and then incubated at $4{ }^{\circ} \mathrm{C}$ overnight. After incubation, tissues were washed in PBS and incubated with the secondary antibody conjugated universal immuno-enzyme polymer using the Histofine MAX PO kit (Nichirei, Tokyo, Japan) for $30 \mathrm{~min}$ at room temperature, washed in PBS and developed by the addition of 3 3'-diaminobenzidine substrate. Finally, the tissues were counterstained with hematoxylin and observed under light microscopy. Normal healthy skins from naturally dead frogs were used as a negative control. [31]

\section{RESULTS}

\section{PCR detection of $\mathrm{Bd}$}

The PCR amplicons of Bd from the skin swab samples, using the Bd-specific ITS1ITS2 primers, showed a positive band of 342 bp (Figure 3). The PCR sensitivity test revealed a limit of detection of $1.02 \times 10^{-1} \mathrm{ng} / \mu \mathrm{l}$. In total, 21 out of the 492 frog skin samples $(4.27 \%)$ were found to be PCR positive for $\mathrm{Bd}$, from one tomato frog (Dyscophus antongilii) and 20 poison dart frogs (Dendrobates tinctorius). All the positive samples were from dead frogs obtained from one zoo (NEZ, No. 4 in Table 1 and Figure 1) and were non-native imported species. Overall, the prevalence of $\mathrm{Bd}$ in the dead amphibians sampled was 12.5\% (21/168), whereas none of the $259 \mathrm{swab}$ samples collected from live free-ranging amphibians or 65 swab samples collected from live zoo amphibians were positive for $\mathrm{Bd}$.

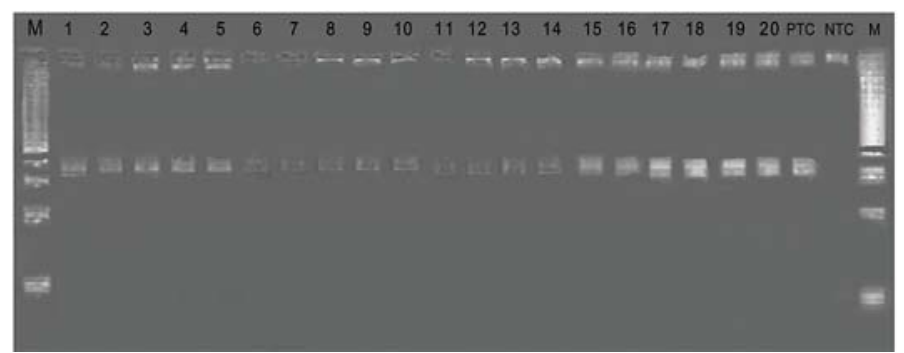

Figure 3. Representative positive PCR amplifications of Bd showing the 342 bp ITS1-ITS2 region amplicon. M:100-bp DNA marker, 1-20:samples, PTC:positive control, NTC: negative control. 
BLASTn searching of the GenBank database and DNA sequence identity analysis revealed that all $\mathrm{Bd}$ detections in this study were from one sequence isolate, designated here as Bd ZFT-CU1 (KU669287), and that this isolate was closely related (98\% nucleotide identity) with various clones of the Bd strain CW34 isolated from the African clawed frog (Xenopus laevis) (JQ582903, JQ582904, JQ582915, JQ582937). The NJ phylogenetic tree depicted that Bd ZFT-CU1 was not closely associated with the global panzootic lineage (Bd-GPL) (Figure 4).

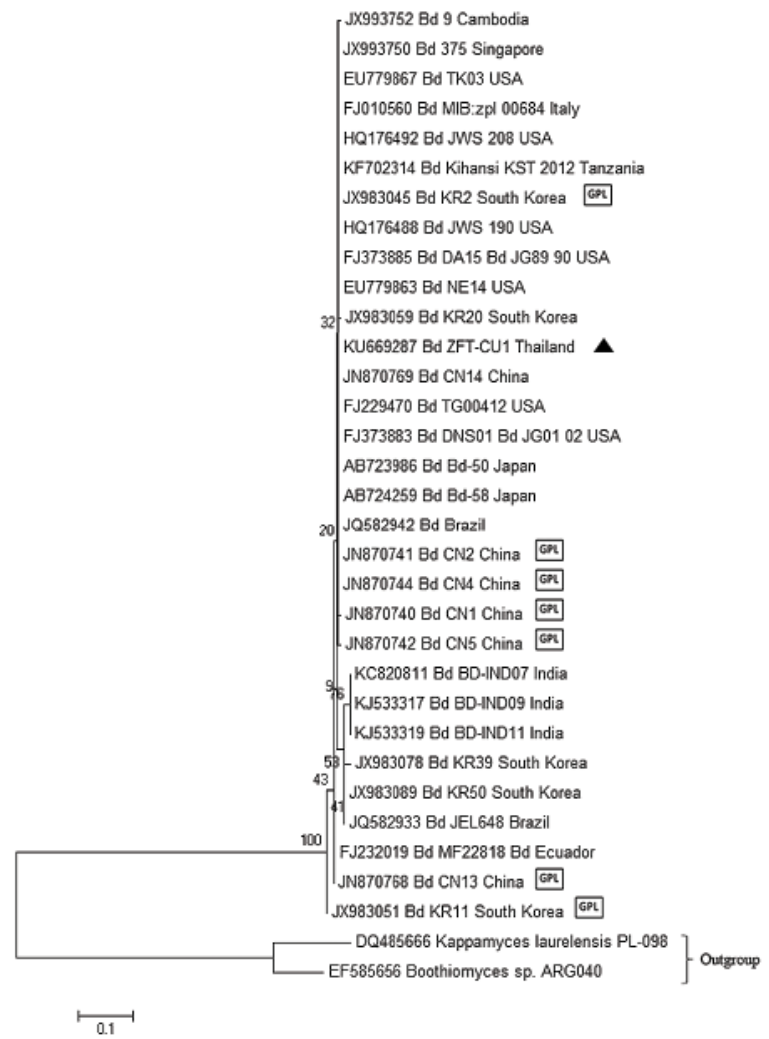

Figure 4. Neighbour-joining phylogenetic dendrogram based upon 298 bp of the ITS1-ITS2 region,comparing the Bd ZFT-CU1 (KU669287) isolate from Thailand (this study) with related $B d$ strains from GenBank. DQ485666 and EF585656were used as outgroup control. GPL: the global panzootic lineage (Bd-GPL). Scale bar shows 0.1 nucleotide substitutions per site.

\section{Histopathology and immunohistology of the Bd infected amphibian's skin}

Histopathological examination of the skin of the 21 PCR-positive samples revealed a positive $\mathrm{Bd}$ phenotype in only $6 / 20$ poison dart frogs and the tomato frog $(1 / 1)$, or a total of $33.33 \%$ of the PCR-positive samples. The epidermis of the poison dart frogs showed multiple chytrid zoosporangia containing zoospores and empty zoosporangia within the keratin layers of the stratum corneum (Figure 5A). The typical 
characteristics of $\mathrm{Bd}$, flask-shaped zoosporangia and septate thalli roughly spherical with a discharge papilla projecting, were evident. In cross section, empty spaces or dark circles of zoosporangia were often seen in the stratum corneum of the affected epidermis. The zoosporangia size varied from $6-10 \mu \mathrm{m}$ in diameter. Vacuolar change of the epidermis accompanied with ballooning degeneration was observed without any ulcerative dermatitis or hyperkeratosis of the epidermis. Scattered lymphocytic infiltration in the epidermis was also found. The septate thalli, sporangia containing zoospores were clearly visible by GMS staining (data not shown).

The immunohistochemical stained sections showed a positive dark brown color at the zoosporangium wall. A strong positive reaction was clearly evident in the zoosporeladen zoosporangia (Figure 5B).

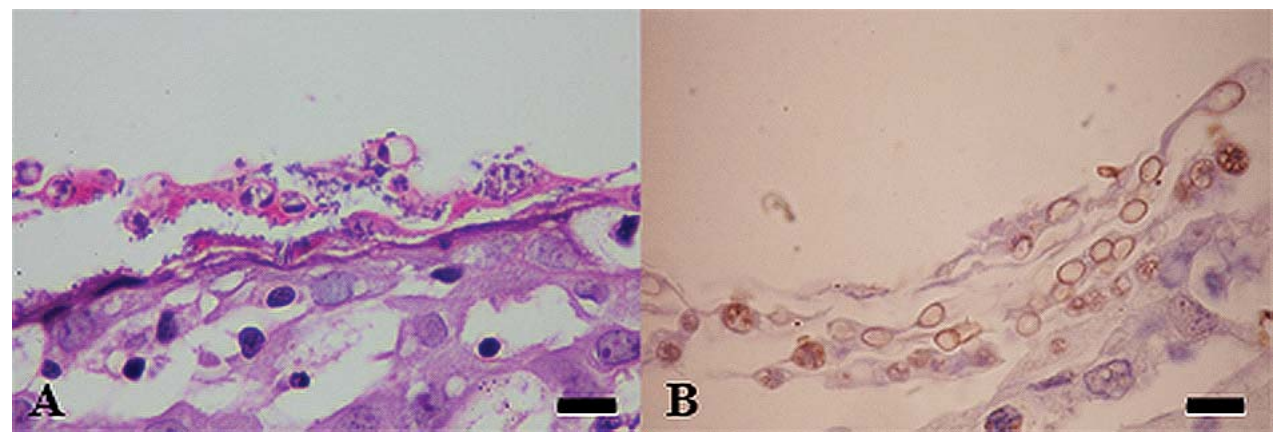

Figure 5. Histopathological appearance of Bd in the poison dart frog's skin showed the empty zoosporangium and zoosporangium with zoospores in the epidermis layer. (A) $H \& E$ and (B) immunohistochemistry using anti-Bd antibody $(\mathrm{Bar}=10 \mu \mathrm{m})$.

\section{DISCUSSION}

With respect to the Year of the Frog 2008, designated by the association of zoos and aquariums and several other environmental organizations, a working group that consisted of veterinarians and herpetologists was established in Thailand in order to systematically survey and monitor the presence of deadly fungal diseases in both captive and wild amphibians. A survey of emerging Bd infections in national zoo and free-ranging amphibians across the country was organized during 2009-2012 with the aim to screen for the presence of $\mathrm{Bd}$ in as many species as possible, including the relative species abundance, and from as many sites as possible. The study confirmed the presence of chytridiomycosis in two introduced frog species in one zoo in Thailand, but not in any samples of native amphibians, either in zoo captivity or in free-ranging areas. The histopathology and immunohistochemistry revealed the typical characteristics of chytridiomycosis in the animal carcasses, suggesting chytridiomycosis was the likely underlying cause of death.

The emergence of chytridiomycosis has contributed to amphibian population declines in other continents within the last 20 years $[1,8,15,35]$, while $\mathrm{Bd}$ appears to be widely 
distributed throughout Asia, including Indonesia [11,36], South Korea [4,13], China [6], Laos [36], Malaysia [36-37] and Cambodia [38-39]. With respect to the bioclimatic conditions, South East Asia is suitable for the establishment of Bd [28-29]. However, when compared with disease emergence seen in other parts of the world, no pandemic or epidemic outbreak has been recorded, except for a lethal outbreak of the disease in Japan $[14,17]$. This is in agreement with our result, where all the samples from live animals (both zoo captives and wild amphibians) were negative for $\mathrm{Bd}$ and there have not been any reports of massive die-offs of native amphibian populations, including at the zoo where the $\mathrm{Bd}$ positive cases were detected in the two imported captive frog species. The prevalence of infection was quite low compared to the pattern of disease emergence seen in other parts of the world, although a higher prevalence was shown among non-native species of amphibians. The NJ phylogenetic analysis revealed the evolutional lineage of Bd ZFT-CU1 was not closely related with the global panzootic lineage ( $B d-\mathrm{GPL})$, where it is not clear if the difference in clinical manifestation and virulence finding may be due to intraspecific diversity of $\mathrm{Bd}$ lineages [3,23], different amphibian resistance levels or the regional presence of antifungal symbionts [40]. According to Bataille et al. (2013), Bd is endemic to Asia as a potentially benign pathogen, and if so then Asian amphibians have probably evolved mechanisms of resistance to or tolerance for at least the local endemic strains of $\mathrm{Bd}$ and hence chytridiomycosis. It is also not clarified how biotic or abiotic environmental factors could modulate the virulence of Bd, as suggested by Bataille et al. (2013) [4]. An extensive variation in host responses within and among species or even within the same amphibian family has been experimentally documented [15]. Genotypic differences among pathogen isolates can directly affect virulence [22-23].

In Thailand, the occurrence of $\mathrm{Bd}$ was detected from the carcasses of imported, non-native poison dart frogs in captivity in a zoo in Bangkok by histopathology and immunohistochemistry [31], without a history of mass-die-off. However, in the natural habitat of Thailand, the occurrence of Bd was previously recorded by PCR analysis from an adult native lesser toad, Ingerophrynus parvus, from Peninsular Thailand in 2012 during a PCR-based survey of the amphibian fauna of the Prince of Songkla University Protected Area [41], again with no evidence of a disease outbreak. A retrospective survey of the presence of $\mathrm{Bd}$ by histological screening of 123 amphibian specimens (28 species) collected in the last 60 years from 13 provinces in Thailand did not find any Bd-positive samples [42]. However, histological examination is not the most powerful (sensitive) method for the detection of Bd [43-44], as seen in the present study where only 7/21 PCR-positive samples were found to be positive for Bd by histology.

In conclusion, we confirmed the emergence of $\mathrm{Bd}$ in captive amphibians in Thailand by histopathology, immunohistochemistry and PCR-sequencing techniques. The importance of zoo amphibians as sources of pathogen (especially fungi and viruses) replication and diffusion to the environment, including $\mathrm{Bd}$, as well as the potential threat to wild species, should be a major part of future work. Until now, there was no 
report of Bd outbreaks in amphibian zoo in Thailand. However, establishing the early detection of $\mathrm{Bd}$ presence, the control measures and the study of ecological biodiversity of Thai amphibians would be a crucial step to monitoring after introduction into native free ranging and captive amphibians. Large scale surveillance across the country should be further established.

\section{Acknowledgements}

The authors are grateful for financial support from Zoological Park of Thailand and Chulalongkorn University (GSTAR 59-004-31-003).

\section{Authors' contributions}

AS collected samples and performed the experiment. SK, BS and WK collected samples and discussed the results. ST and NP designed and performed the experiment, discussed the results, drafted and finalized the manuscript. All authors read and approved the final manuscript.

\section{Declaration of conflicting interests}

The author(s) declared no potential conflicts of interest with respect to the research, authorship, and/or publication of this article.

\section{REFERENCES}

1. Berger L, Speare R: Chytridiomycosis: a new disease of wild and captive amphibians. ANZCCART Newsletter 1998, 11:1-3.

2. Longcore JE, Pessier AP, Nichols DK: Batrachochytrium dendrobatidis gen. et sp. nov., a chytrid pathogenic to amphibians. Mycologia 1999, 91:219-227.

3. Berger L, Roberts AA, Voyles J, Longcore JE, Kris A. Murray KA, Skerratt LF: History and recent progress on chytridiomycosis in amphibians. Fungal Ecol 2016, 19:89-99.

4. Bataille A, Fong JJ, Cha M, Wogan GO, Baek HJ, Lee H, Min MS, Waldman B: Genetic evidence for a high diversity and wide distribution of endemic strains of the pathogenic chytrid fungus Batrachochytrium dendrobatidis in wild Asian amphibians. Mol Ecol 2013, 22:4196-4209.

5. Skerratt L, Berger L, Speare R, Cashins S, McDonald KR, Phillott AD, Hines HB, Kenyon $\mathrm{N}$ : Spread of chytridiomycosis has caused the rapid global decline and extinctionof frogs. EcoHealth 2007, 4:125-134.

6. Bai C, Garner TWJ, Li Y: First evidence of Batrachochytrium dendrobatidis in China: discovery of Chytridiomycosis in introduced American bullfrogs and native amphibians in the Yunnan province, China. Ecohealth 2010, 7:127-134.

7. Berger L, Speare R, Kent A: Diagnosis of chytridiomycosis in amphibians by histologic examination. Zoos' Print J 2000, 15:184-190. 
8. Bosch J, Martınez-Solano I, Garcia-Parıs M: Evidence of a chytrid fungus infection involved in the decline of the common midwife toad (Alytes obstetricans) in protected areas of central Spain. Biol Conserv 2001, 97:331-337.

9. Garner TWJ, Walker S, Bosch J, Hyatt AD, Cunningham AA, Fisher MC: Chytrid fungus in Europe. Emerg Infect Dis 2005, 11:1639-1641.

10. Hopkins S, Channing A: Chytrid fungus in northern and western Cape frog populations, South Africa. Herpetol Rev 2003, 34:334-336.

11. Kusrini MD, Skerratt LF, Garland S, Berger L, Endarwin W: Chytridiomycosis in frogs of Mount GedePangrango, Indonesia. Dis Aquat Organ 2008, 82:187-194.

12. Raverty S, Reynolds T: Cutaneous chytridiomycosis in dwarf aquatic frogs (Hymenochirus boettgeri) originating from southeast Asia and in a western toad (Bufo boreas) from northeastern British Columbia. Can Vet J 2001, 42:385-386.

13. Yang HJ, Baek HJ, Speare R, Webb R, Park SK, Kim TH, Lasater KC, Shin SP, Son SH, Park JH, Min MS, Kim YJ, Na K, Lee H, Park SC: First detection of the amphibian chytrid fungus Batrachochytrium dendrobatidis in free-ranging populations of amphibians on mainland Asia: survey in South Korea. Dis Aquat Organ 2009, 86:9-13.

14. Une Y, Kadekaru S, Tamukai K, Goka K, Kuroki T: First report of spontaneous chytridiomycosis in frogs in Asia. Dis Aquat Organ 2008, 82:157-160.

15. Fisher MC, Garner TWJ, Walker SF. Global emergence of Batrachochytrium dendrobatidis and amphibian chytridiomycosis in space, time and host. Annu Rev Microbiol 2009, 63:291310 .

16. Olson DH, Aanensen DM, Ronnenberg KL, Powell CI, Walker SF, Bielby J, Garner TW, Weaver G, Fisher MC: Mapping the global emergence of Batrachochytrium dendrobatidis, the amphibian chytrid fungus. PLoS ONE 2013, 8:e56802.

17. Goka K, Yokoyama J, Une Y, Kuroki T, Suzuki K, Nakahara M, Kobayashi A, Inaba S, Mizutani T, Hyatt AD: Amphibian chytridiomycosis in Japan: distribution, haplotypes, and possible route of entry into Japan. Mol Ecol 2009, 18:4757-4774.

18. Weldon C, du Preez LH, Hyatt AD, Muller R, Spears R: Origin of the amphibian chytrid fungus. Emerg Infect Dis 2004, 10:2100-2105.

19. Mazzoni R, Cunningham AA, Daszak P, Apolo A, Perdomo E, Speranza G: Emerging pathogen of wild amphibians in frogs (Rana catesbeiana) farmed for international trade. Emerg Infect Dis 2003, 9:995-998.

20. Schloegel LM, Picco AM, Kilpatrick AM, Davies AJ, Hyatt AD, Daszak P: Magnitude of the US trade in amphibians and presence of Batrachochytrium dendrobatidis and ranavirus infection in imported North American bullfrogs (Rana catesbeiana). Biol Conserv 2009, 142:1420-1426.

21. Fisher MC, Bosch J, Yin Z, Stead DA, Walker J, Selway L, Brown AJP, Walker LA, Gow NAR, Stajich JE, Garner TWJ: Proteomic and phenotypic profiling of the amphibian pathogen Batrachochytrium dendrobatidis shows that genotype is linked to virulence. Mol Ecol 2009, 18:415-429.

22. Becker CG, Greenspan SE, Tracy KE, Dash JA, Lambertini C, Jenkinson TS, Leite DS, Toledo LF, Longcore JE, James TY, Zamudio KR: Variation in phenotype and virulence among enzootic and panzootic amphibian chytrid lineages. Fungal Ecol 2017, 26:45-50.

23. Gervasi SS, Stephens PR, Hua J, Searle CL, Xie GY, Urbina J, Olson DH, Bancroft BA, Weis V, Hammond JI, Relyea RA, Blaustein AR: Linking ecology and epidemiology to understand predictors of multi-host responses to an emerging pathogen, the amphibian chytrid fungus. PLoS ONE 2017, 12:e0167882. 
24. Farrer RA, Weinert LA, Bielby J, Garner TWJ, Balloux F, Francis C, Bosch J, Cunninghma AA, Weldon C, du Preez LH, Anderson L, Kosakovsky PSL, Shahar-Golan R, Henk DA, Fisher MC: Multiple emergences of genetically diverse amphibian infecting chytrids include a globalized hypervirulent recombinant lineage. P Natl Acad Sci USA 2011, 108:1873218736.

25. Lips K: A tale of two lineages: unexpected, long-term persistence of the amphibian-killing fungus in Brazil. Mol Ecol 2014, 23:747-749.

26. Schloegel LM, Toledo LF, Longcore JE, Greenspan SE, Vieira CA, Lee M, Zhao S, Wangen C, Ferreira C, Hipolito M: Novel, panzootic and hybrid genotypes of amphibian chytridiomycosis associated with the bullfrog trade. Mol Ecol 2012, 21:5162-5177.

27. Bletz MC, Rosa GM, Andreone F, Courtois EA, Schmeller DS, Rabibisoa NH, Rabemananjara FC, Raharivololoniaina L, Vences M, Weldon C, Edmonds D, Raxworthy CJ, Harris RN, Fisher MC, Crottini A: Widespread presence of the pathogenic fungus Batrachochytrium dendrobatidis in wild amphibian communities in Madagascar. Sci Rep 2015, 5:8633.

28. Rödder D, Kielgast J, Lötters S: Future potential distribution of the emerging amphibian chytrid fungus under anthropogenic climate change. Dis Aquat Organ 2010, 92:201-207.

29. Ron SR: Predicting the distribution of the amphibian pathogen Batrachochytrium dendrobatidisin the new world. Biotropica 2005, 37:209-221.

30. Teixeira RD, Pereira Mello SCR, Lima dos Santos CAM: The world market for frog legs. FA O, Rome. Globefish version 2001, 68:1-44.

31. Pirarat N, Sommanustweechai A, Sailasuta A, Kamolnorranart S, Une Y, Siriaroonrat B: Immunohistochemical identification of chytridiomycosis in poison dart frogs (Dendrobates tinctorius) in Thailand [abstract]. Proceeding of the $4^{\text {th }}$ Asian Society of Veterinary Pathologists Conference, Bangkok, Thailand 2009, 436.

32. Puschendorf R, Bolanos F: Detection of Batrachochytrium dendrobatidisin Eleutherodactylus fitzingeri: effects of skin sample location and histologic skin. J Wildlife Dis 2006, 42:301306.

33. Annis SL, Dastoor FP, Ziel H, Daszak P, Longcore JE: A DNA-based assay identifies Batrachochytrium dendrobatidis in amphibians. J Wildlife Dis 2004, 40:420-428.

34. Tamura K, Stecher G, Peterson D, Filipski A, Kumar S: MEGA6: Molecular Evolutionary Genetics Analysis Version 6.0. Mol Biol Evol 2013, 30:2725-2729.

35. Kilpatrick AM, Briggs CJ, Daszak P: The ecology and impact of chytridiomycosis: an emerging disease of amphibians. Trends Ecol Evol 2009, 25:109-118.

36. Swei A, Rowley JJ, Rödder D, Diesmos ML, Diesmos AC, Briggs CJ, Brown R, Cao TT, Cheng TL, Chong RA, Han B, Hero JM, Hoang HD, Kusrini MD, Le DT, McGuire JA, Meegaskumbura M, Min MS, Mulcahy DG, Neang T, Phimmachak S, Rao DQ, Reeder NM, Schoville SD, Sivongxay N, Srei N, Stöck M, Stuart BL, Torres LS, Tran DT, Tunstall TS, Vieites D, Vredenburg VT: Is chytridiomycosis an emerging infectious disease in Asia?. PLoS One 2011, 6:e23179.

37. Savage AE, Grismer LL, Anuar S, Onn CK, Grismer JL, Quah E, Muin MA, Ahmad N, Lenker M, Zamudio KR: First record of Batrachochytrium dendrobatidis infecting four frog families from Peninsular Malaysia. EcoHealth 2011, 8:121-128.

38. Gaertner JP, Mendoza JA, Neang T, Forstner MJR, Hahn D: Detection of Batrachochytrium dendrobatidis in frogs from different locations in Cambodia. Herpetol Rev 2011, 42:546-549.

39. Mendoza JA, Gaertner JP, Holden J, Forstner MJR, Hahn D: Detection of Batrachochytrium dendrobatidis on amphibians in Pursat Province, Cambodia. Herpetol Rev 2011, 42:542-545. 
40. Park ST, Collingwood AM, St-Hilaire S, Sheridan PP: Inhibition of Batrachochytrium dendrobatidis caused by bacteria isolated from the skin of boreal toads, Anaxyrus (Bufo) boreas boreas, from Grand Teton National Park, Wyoming, USA. Microbiol Insights 2014, 7:1-8.

41. Vörös J, Satasook C, Bates P, Wangkulangkul S: First record of the amphibian chytrid fungus, Batrachochytrium dendrobatidis in Thailand. Herpetology Notes 2012, 5:519-521.

42. McLeod DS, Sheridan JA, Jiraungkoorskul W, Khonsue W: A survey for chytrid fungus in Thai amphibians. Raffles B Zool 2008, 56:199-204.

43. Boyle DG, Boyle DB, Olsen V, Morgan JA, Hyatt AD: Rapid quantitative detection of chytridiomycosis (Batrachochytrium dendrobatidis) in amphibian samples using real-time Taqman PCR assay. Dis Aquat Organ 2004, 60:141-148.

44. Kriger KM, Hines HB, Hyatt AD, Boyle DG, Hero JM: Techniques for detecting chytridiomycosis in wild frogs: comparing histology with real-time Taqman PCR. Dis Aquat Organ 2006, 71:141-148.

\title{
POJAVA MIKOZE BATRACHOCHYTRIUM DENDROBATIDIS, KOD VODOZEMACA U ZOOLOŠKIM VRTOVIMA NA TAJLANDU
}

\author{
TECHANGAMSUWAN Somporn, SOMMANUSTWEECHAI Angkana, \\ KAMOLNORRANART Sumate, SIRIAROONRAT Boripat, \\ KHONSUE Wichase, PIRARAT Nopadon
}

Hitridiomikoza, bolest amfibija koju izaziva Batrachochytrium dendrobatidis od 1996. godine je dovela do opadanja populacije i nestanka nekih vrsta žaba. Cilj ove studije je bio da odredimo prevalencu kao i potrebu formiranja sistema za nadzor i monitoring hitridiomikoze u pet nacionalnih zooloških vrtova i pet zaštićenih rezervata širom Tajlanda. Ukupno je 492 uzoraka sakupljenih sa živih i uginulih životinja testirano PCR metodom na prisustvo Bd-a. Pozitivni uzorci su potvrđeni sekvencioniranjem, a uz to histopatološki i imunohistohemijski dodatno ispitani. U periodu od jula 2009. do avgusta 2012. prevalenca BD određena PCR-om na uzorcima kože je bila niska (4,27\%). Svi uzorci uzeti sa živih amfibija su bili negativni. Pozitivni uzorci bili su isključivo sa uginulih žaba $(21 / 168 ; 12,5 \%)$ koje nisu autohtone vrste i to: otrovna žaba (Dendrobates tinctorius) i žaba (Dyscophus antongilii) čuvane u jednom od zooloških vrtova. Imunohistohemija i histopatologija su ukazale na tipičnu građu u obliku boce zoosporangija i septiranih talusa. Na ovaj način je podržan PCR nalaz hitridiomikoze kod vodozemaca u zarobljeništvu u Tajlandu, ali je BD detektovan u svega 7/21 PCR pozitivnih uzoraka. Iako uvođenje patogenih sojeva BD preko uveženih prenosioca može da ima značajan efekat na domaću populaciju amfibija na Tajlandu, hitridiomikoza još uvek nije detektovana u domaćoj populaciji amfibija. U cilju monitoringa eventualnog prelaska gljivice na populaciju na Tajlandu neophodno je razviti adekvatan nadzorni sistem. 